\title{
DETERMINASI KEPUTUSAN HEDGING PERUSAHAAN PUBLIK SEKTOR PERTANIAN 2013-2019
}

\author{
Irfani Azzah Nabiilah \\ Universitas Negeri Surabaya \\ irfani.17080574017@mhs.unesa.ac.id
}

\begin{abstract}
A multinational company uses a determination of hedging decisions in international trade. The difference in currency values is a risk that will occur and minimize this risk using hedging. This research's independent variable is firm size, profitability, liquidity, growth opportunity, and leverage. The hedging is the dependent variable. This research used secondary data derived from annual financial reports by quantitative approach. The object used in this research is agricultural sector companies on Indonesia Stock Exchange in 2013-2019 with 11 companies as the sample. The data analysis technique used is logistic regression. This study indicates that profitability proxied by return on assets positively affects the company's hedging decisions. Meanwhile, growth opportunity calculated by using a comparison between the market value of equity and book value of equity, leverage proxied by the debt to assets ratio, liquidity proxied by the current ratio, firm size measured using the natural logarithm of total assets does not affect the company's hedging decisions. This research explains that companies with high profitability should do hedging activities to protect the company from adverse risks.
\end{abstract}

Keywords: hedging; leverage; likuiditas; profitabiltas; ukuran perusahaan

\section{PENDAHULUAN}

Perdagangan internasional merupakan interaksi ekonomi dengan berbagai negara dalam wilayah internasional pada era globalisasi (Wayan, Mitariani, Sedana, \& Badjra, 2013). Dalam melakukan ekspansi pasar, perusahaan dapat melakukan perdagangan internasional (Saraswati \& Suryantini 2019). Multinational company dapat melakukan penetrasi pasar luar negeri serta melakukan pendekatan konservatif guna mendapatkan kesepakatan harga yang baik mengenai bahan baku (Madura, 2012). Terjadi fluktuasi nilai tukar USD terhadap IDR dari tahun 2013 hingga 2019. Terjadinya penurunan kurs transaksi USD pada tahun 2014, kemudian kembali meningkat pada tahun 2015 hingga 2019. Perkembangan pada 7 tahun terakhir nilai tukar USD terhadap rupiah terdepresiasi (Indonesia \& Republik Indonesia, 2020).

Terdapat sisi positif dan negatif yang terjadi pada perusahaan ketika utang luar negeri digunakan untuk pembiayaan (Indawan, Fitriani, Karlina, \& Grace, 2015). Utang luar negeri digunakan untuk pembiayaan bagi multinational company guna terlaksananya ekspansi usaha merupakan sisi positif yang dapat terjadi, dan sisi negatifnya adalah utang luar negeri yang tinggi dapat menimbulkan risiko yang disebabkan oleh perubahan mata uang. Perubahan nilai kurs mata uang dapat menjadi risiko pada penjualan. Dalam perdagangan internasional terdapat kemungkinan terjadinya depresiasi mata uang lokal, apabila hal ini terjadi maka perusahaan akan mengeluarkan nilai mata uang lokal yang lebih tinggi ketika melakukan interaksi, sehingga dapat menyebabkan kerugian pada perusahaan (Astyrianti \& Sudiartha 2017). Perekonomian Indonesia yang tidak stabil menyebabkan perusahaan untuk dapat melakukan ekspansi usaha, hal yang dipilih adalah melakukan pembiayaan melalui utang luar negeri (Kurniawan \& Asandimitra 2018). Perkembangan total Utang Luar Negeri (ULN) selama periode 2013-2019 dapat dilihat pada gambar 1. 


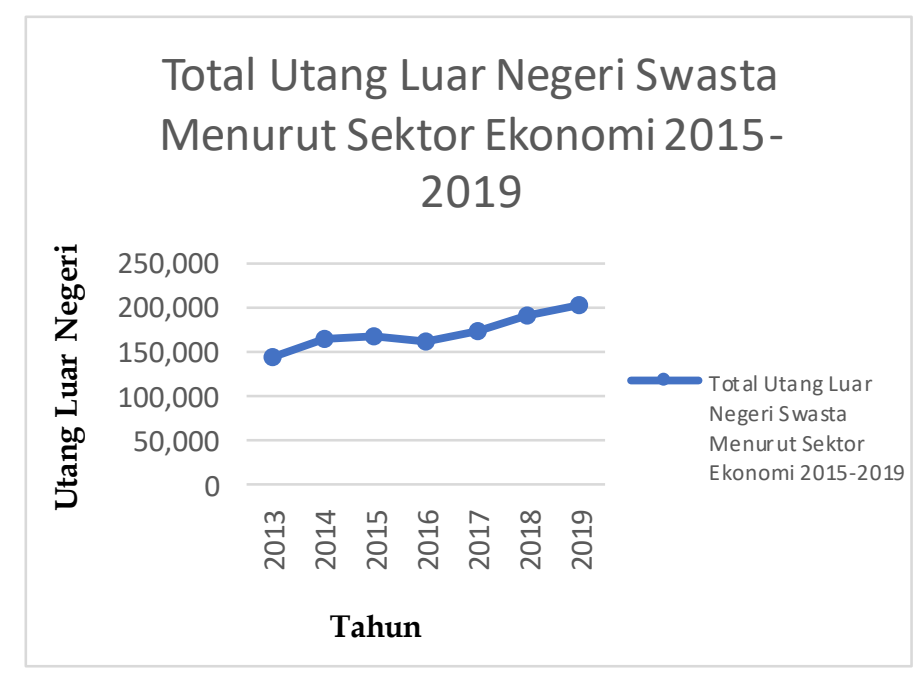

\section{Sumber: Bank Indonesia 2020, diolah penulis \\ Gambar 1. TOTAL UTANG LUAR NEGERI SWASTA MENURUT SEKTOR EKONOMI 2013-2019}

Utang luar negeri swasta mengalami peningkatan sejak tahun 2013. Utang luar negeri dalam bentuk rupiah dan atau mata uang asing yang dilakukan oleh penduduk kepada bukan penduduk dengan berlandaskan perjanjian disebut dengan utang luar negeri swasta.

Total utang luar negeri swasta tahun 2013-2019 yang diperoleh dari masing-masing sektor ekonomi, perusahaan sektor pertanian memiliki kecenderungan menurun, naiknya utang luar negeri terjadi tahun 2015, namun kenaikan ini tidak signifikan yaitu 8.298 juta USD, kemudian turun kembali 7.003 juta USD tahun 2016 seperti pada gambar 2.

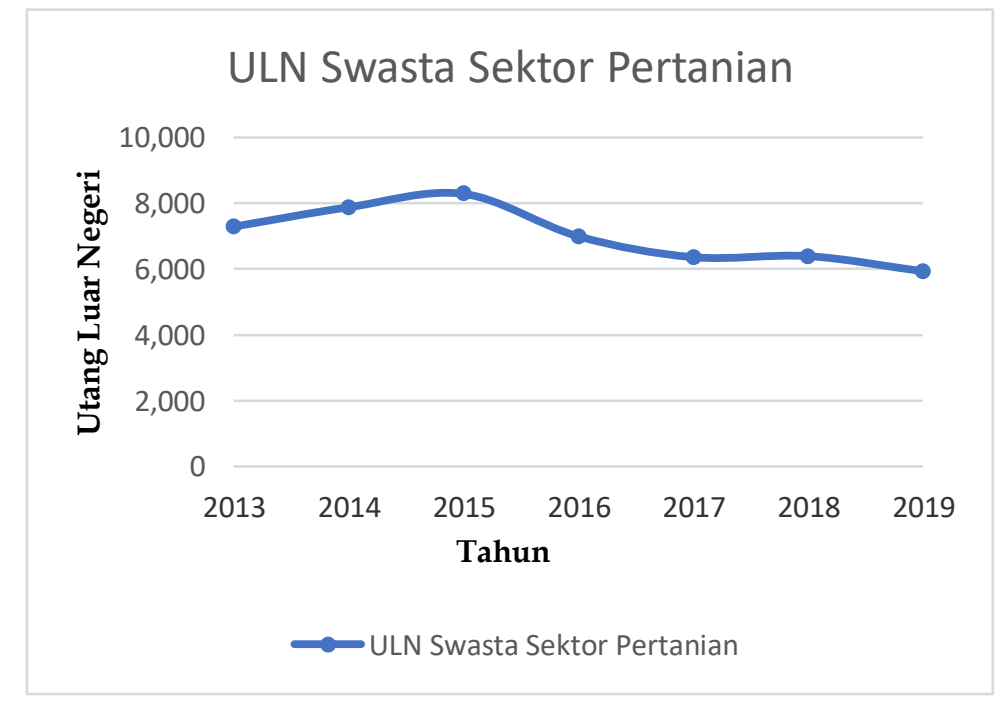

Sumber: Bank Indonesia 2020, diolah penulis

\section{Gambar 2. POSISI UTANG LUAR NEGERI SWASTA SEKTOR PERTANIAN 2013-2019}

Pada peraturan Bank Indonesia Nomor 16/21/PBI/2014 yang menjelaskan bahwa melakukan transaksi lindung nilai atas valuta asing terhadap rupiah menjadi kewajiban dari korporasi nonbank yang memiliki utang luar negeri dalam valuta asing sehingga memenuhi rasio lindung nilai minimum tertentu. Hal ini menggambarkan bahwa semakin tinggi posisi utang luar negeri maka pada korporasi nonbank (Swasta) diharapkan semakin tinggi pula kebijakan hedging (lindung nilai) yang ditetapkan, di sini terlihat ada hubungan searah antara utang luar negeri dengan kebijakan hedging. 
Irfani Azzah Nabiilah. Determinasi Keputusan Hedging Perusahaan Publik Sektor Pertanian 20132019

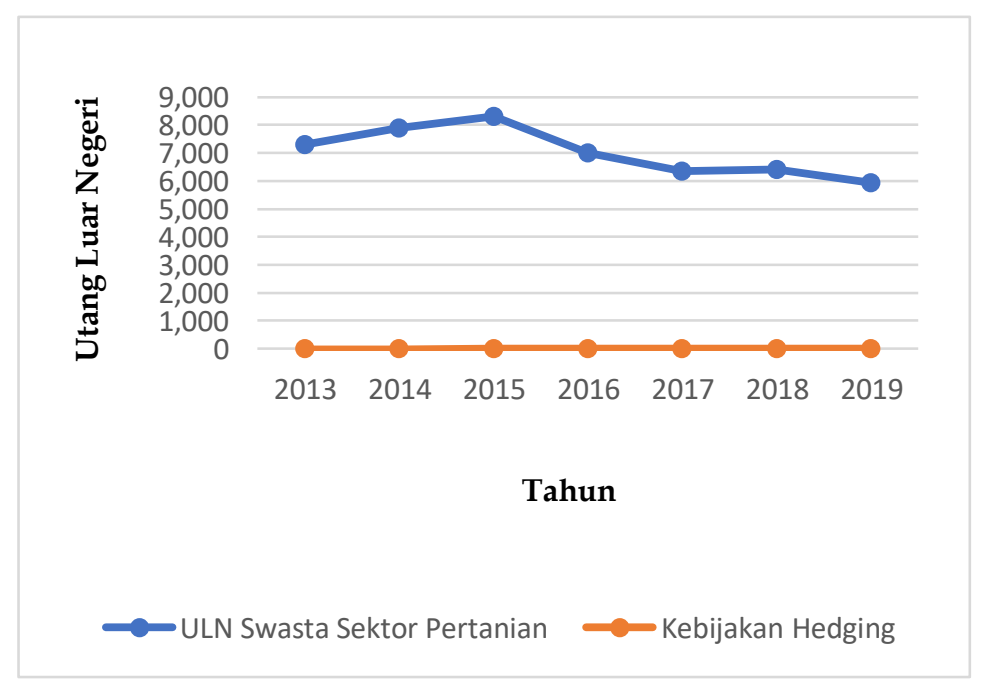

\section{Sumber: Bank Indonesia 2020, diolah penulis \\ Gambar 3. PERBANDINGAN PERKEMBANGAN ULN SWASTA SEKTOR PERTANIAN DAN KEBIJAKAN HEDGING 2013-2019}

Pada utang luar negeri swasta sektor pertanian yang mengalami penurunan, terlihat pada gambar 3 perusahaan swasta yang menetapkan kebijakan hedging justru mengalami peningkatan dari tahun 2013 hingga 2019. Utang luar negeri swasta di sektor pertanian mengalami penurunan, di mana pada sektor lainnya justru mengalami peningkatan. Di sisi lain fluktuasi kurs pada rupiah mengalami depresiasi. Dalam melakukan manajemen risiko perusahaan dapat melakukan hedging pada utang yang dimilikinya guna meminimalisir risiko dari perubahan nilai tukar mata uang. Namun, perusahaan di sektor pertanian yang memilih keputusan hedging justru meningkat tahun 2013-2019 di samping utang luar negeri swasta pada sektor pertanian yang mengalami penurunan.

Ukuran perusahaan merupakan variabel pertama yang dapat memengaruhi keputusan hedging. Besar atau kecilnya perusahaan digambarkan pada besarnya ukuran perusahaan. Penjualan, total aset, dan ekuitas menjadi indikator dalam mengukur besarnya perusahaan (Saraswati \& Suryantini, 2019). Ukuran perusahaan memiliki pengaruh terhadap keputusan hedging (Windari \& Purnawati, 2019). Namun Wahyudi et al. (2019), ukuran perusahaan tidak berpengaruh terhadap keputusan hedging.

Growth opportunity merupakan variabel kedua yang dapat memengaruhi keputusan hedging. Growth opportunity menyebabkan kebutuhan dana yang dibutuhkan untuk pertumbuhan perusahaan menjadi besar (Astyrianti \& Sudiartha, 2017). Growth opportunity memiliki pengaruh terhadap keputusan hedging (Saragih \& Musdholifah, 2017). Hasil tersebut berbeda degan Aristya \& Hidajah (2020), bahwa growth opportunity tidak memiliki pengaruh terhadap keputusan hedging.

Leverage merupakan variabel ketiga yang dapat memengaruhi keputusan hedging. Dalam mengukur kemampuan perusahaan melunasi kewajibannya dapat dideteksi dari rasio leverage (Diah Windari \& Purnawati, 2019). Leverage memiliki pengaruh terhadap keputusan hedging (Kurniawan \& Asandimitra, 2018). Namun Idawati \& Redawati (2019) menyatakan leverage tidak memiliki pengaruh terhadap keputusan hedging.

Likuiditas merupakan variabel keempat yang dapat memengaruhi keputusan hedging. Daya mampu perusahaan dalam mencukupi utang lancar dapat dideteksi melalui rasio likuiditas (Bodroastuti, Paranita, \& Ratnasari, 2019). Likuiditas memiliki pengaruh terhadap keputusan hedging (Astyrianti \& Sudiartha (2017). Namun menurut Prabawati \& Damayanti (2019), likuiditas tidak memiliki pengaruh terhadap keputusan hedging. Profitabilitas merupakan variabel kelima yang yang dapat memengaruhi keputusan hedging. Kemampuan perusahaan dalam memeroleh keuntungan dapat dilihat melalui rasio profitabilitas (Limbong \& Hutabarat, 2020). Profitabilitas memiliki pengaruh terhadap keputusan 
hedging (Hadinata \& Hardianti, 2019). Hasil tersebut bertentangan dengan Aristya \& E Hidajah (2020), profitabilitas tidak memiliki pengaruh terhadap keputusan hedging. Atas dasar ini, tujuan penelitian untuk menganalisis pengaruh ukuran perusahaan, growth opportunity, profitabilitas. leverage, dan likuiditas terhadap keputusan hedging perusahaan publik sektor pertanian 2013-2019.

\section{KAJIAN PUSTAKA DAN PENGEMBANGAN HIPOTESIS}

\section{Teori Portofolio}

Teori portofolio menjelaskan bahwa dengan aset lain yang ditambahkan pada portofolio dengan ekspektasi pengembalian yang masih dalam rataan ekspektasi yang tertimbang pada masing-masing aset dalam portofolio akan membuat risiko portofolio investasi tersebut berkurang (Kodrat \& Herdinata, 2009:6). Risiko sistematis dan tidak sistematis merupakan dua macam risiko pada portofolio. Dengan terlindunginya nilai portofolio dan berkurangnya pergerakan pasar yang dapat merugikan perusahaan, dalam meminimalisir risiko sistematis perusahaan dapat menggunakan hedging (Tandelilin, 2010:484).

\section{Signaling Theory}

Signaling theory menyatakan bahwa para investor akan diberikan informasi atau petunjuk dari pihak manajemen perusahaan atas kondisi yang terjadi pada perusahaanya (Brigham \& Houston 2014). Informasi simetris (symmetric information) adalah informasi yang sama dan diterima oleh manajer serta investor mengenai prospek suatu perusahaan. Namun pada kenyataannya, dengan adanya asimetri informasi (asymmetric information) informasi yang dimliki oleh jajaran manajer lebih baik daripada para investor. Perusahaan memiliki asimetris informasi sehingga memilih untuk melakukan pendanaan eksternal berupa utang dalam membiayai peluang pertumbuhan. Hal ini akan menimbulkan risiko bagi perusahaan sehingga untuk meminimalisir risiko tersebut perusahaan memilih untuk melakukan hedging (Sasmita \& Hartono, 2019).

\section{Trade-off theory}

Teori pertukaran leverage menjadi sebutan bagi trade-off theory, supaya perusahaan mendapatkan keringanan dari membayar pajak, perusahaan akan menggunakan utang yang dimilikinya (Brigham \& Houston 2014). Ketika berkurangnya beban pajak menjadi tujuan dari pembayaran bunga, maka utang akan lebih mudah dibayarkan daripada saham biasa atau preferen. Bertambahnya laba operasi perusahaan dan berkurangnya tanggungan pajak terjadi karena utang yang digunakan perusahaan dalam jumlah besar sehingga sebagai upaya manajemen risiko perusahaan dapat melakukan hedging. Semakin tinggi risiko yang timbul maka kemungkinan perusahaan memilih keputusan hedging semakin besar. Hal ini karena adanya leverage yang dibebankan (Ambarwati, 2010:49).

\section{Pecking Order Theory}

Dalam memenuhi kebutuhan, perusahaan dapat menerapkan kebijakan penjualan aset yang ada, hal ini dijelaskan pada teori pecking order theory (Fahmi, 2012:113). Kemampuan perusahaan dalam memenuhi kebutuhan dana dari dalam perusahaan dapat ditunjukkan melalui tinggi rendahnya likuiditas perusahaan. Saat terjadinya depresiasi pada nilai tukar mata uang hal ini akan memerburuk kondisi yang disebabkan oleh adanya utang yang didenominasi valuta asing, sehingga membuat perusahaan memutuskan untuk melakukan hedging guna meminimalisir risiko yang ada (Fahmi, 2012:113).

\section{Du Pont Theory}

Teori yang menggambarkan tentang faktor dari pengaruh kinerja keuangan yang berkaitan dengan penjualan, utang, jumlah aset, dan pendapatan atas kondisi keuangan suatu perusahaan disebut $d u$ pont theory (Sudana, 2015:27). Du pont theory menjelaskan hubungan antara ROA dan ROE dengan rasio-rasio keuangan lainnya. Tingkat efisiensi penggunaan aset dan mengukur profitabilitas dengan penggunaan $\mathrm{Du}$ pont theory. Profitabilittas yang tinggi pada perusahaan memiliki kesempatan dalam melakukan perluasan aktivitas bisnis hingga luar negeri menggunakan valuta asing. Penggunaan 
Irfani Azzah Nabiilah. Determinasi Keputusan Hedging Perusahaan Publik Sektor Pertanian 20132019

valuta asing menyebabkan perusahaan terdorong untuk memilih keputusan hedging dalam meminimalisir risiko yang terjadi (Sasmita \& Hartono, 2019).

\section{Hedging}

Dalam setiap kegiatan operasional perusahaan pasti tidak luput dari berbagai risiko yang harus dihadapi. Sebagai upaya untuk meminimalisir risiko atas kerugian yang terjadi hal yang dapat dilakukan perusahaan adalah melakukan manajemen risiko. Lindung nilai (hedging) melalui instrumen derivatif seperti kontrak forward, kontrak berjangka, opsi mata uang dan swap menjadi pilihan yang dilakukan perusahaan dalam mengelola risiko dari fluktuasi harga komoditas, suku bunga, serta fluktuasi kurs mata uang dalam perdagangan internasional (Keown, Martin, Petty, \& Junior, 2010).

\section{Ukuran Perusahaan}

Ukuran perusahaan digunakan untuk mengetahui besar atau kecilnya perusahaan berdasarkan total nilai aset, total ekuitas dan total penjualan (Saraswati \& Suryantini 2019). Aktivitas yang dilakukan perusahaan dapat dipengaruhi oleh ukuran perusahaan. Semakin mudah untuk memeroleh pendanaan dan lebih luas dalam menjalankan usahanya terjadi karena ukuran perusahaan yang besar serta semakin mudah mengakses ke pasar modal (Saragih \& Musdholifah 2017). Menurut Bodroastuti et al. (2019) ukuran perusahaan dapat dihitung dengan rumus (1).

Ukuran Perusahaan $=$ Ln $\times$ Total Assets

\section{Growth Opportunity}

Terwujudnya perusahaan menjadi lebih besar merupakan harapan dari pemilik perusahaan dan investor atas tingginya growth opportunity (Astyrianti \& Sudiartha 2017). Ada hubungan saling terkait mengenai growth opportunity dan kebutuhan pendanaan. Kebutuhan dana yang harus diperoleh menjadi lebih besar karena perusahaan memiliki pertumbuhan yang tinggi. Surplus dan rasio utang terhadap modal mengalami penurunan terjadi karena perusahaan dengan taraf pertumbuhan yang relatif rendah. Menurut Wahyudi et al. (2019) growth opportunity dapat dihitung dengan rumus (2).

Growth Opportunity $=\frac{M V E}{B V E}$

\section{Leverage}

Penggunaan biaya tetap yang mampu meningkatkan atau menaikkan profitabilitas disebut dengan leverage (Horne et al., 2013:138). Aset perusahaan dan sumber dana yang diperoleh dalam melakukan kegiatan operasional perusahaan menyebabkan adanya beban tetap bagi perusahaan, hal ini terjadi karena adanya leverage. Menurut Kurniawan \& Asandimitra (2018) leverage dapat dihitung dengan rumus (3).

Debt to Asset Ratio $=\frac{\text { Total Debt }}{\text { Total Assets }}$

\section{Likuiditas}

Daya mampu perusahaan dalam memenuhi utang lancar dapat diketahui melalui banyaknya sumber daya milik perusahaan yang digunakan, ukuran ini disebut dengan likuiditas (Rahardjo, 2007:11). Perusahaan likuid merupakan perusahaan yang dapat membayar utang jangka pendek sebelum batas waktu yang ditetapkan. Menurut Idawati \& Redawati (2019) likuiditas dapat dihitung dengan rumus (4).

Debt to Asset Ratio $=\frac{\text { Total Debt }}{\text { Total Assets }}$ 


\section{Profitabilitas}

Profitabilitas adalah ukuran yang didapatkan perusahaan pada periode tertentu untuk mengetahui laba atau keuntungan yang didapatkan (Kasmir, 2016:196). Memeroleh keuntungan secara maksimal merupakan tujuan perusahaan. Ketika ada investasi baru dan mutu produk perusahaan meningkat hal ini dapat mengindikasi tercapainya target keuntungan perusahaan. Menurut Saraswati \& Suryantini (2019) profitabilitas dapat dihitung dengan rumus (5).

Debt to Asset Ratio $=\frac{\text { Total Debt }}{\text { Total Assets }}$

\section{Hubungan antar Variabel}

Aktivitas perusahaan yang semakin luas dan memiliki kemungkinan memasuki pasar luar negeri digambarkan melalui besarnya ukuran perusahaan (Saraswati \& Suryantini 2019). Menurut Windari \& Purnawati (2019) ukuran perusahaan memiliki pengaruh terhadap keputusan hedging namun hal ini bersimpangan dengan hasil yang dilakukan oleh Aditya \& Asandimitra (2019) yang menyebutkan bahwa ukuran perusahaan tidak memiliki pengaruh terhadap keputusan hedging. Ukuran perusahaan yang besar akan mengakibatkan kemungkinan perusahaan melakukan hedging tinggi karena hedging menjadi upaya perusahaan untuk melakukan perlindungan terhadap aset dan arus kas yang terpapar risiko perubahan kurs mata uang, hal ini didukung oleh teori portofolio. Probabilitas hedging perusahaan semakin tinggi karena ukuran perusahaan yang besar (Kussulistyanti \& Mahfudz 2016).

H1: Ukuran perusahaan berpengaruh terhadap keputusan hedging perusahaan sektor pertanian tahun 2013-2019.

Perusahaan yang mempunyai kesempatan untuk maju tinggi akan ditunjukkan melalui perusahaan yang mengalami growth opportunity, sehingga growth opportunity menjadi besar karena adanya dana yang dibutuhkan perusahaan (Saragih \& Musdholifah 2017). Growth opportunity memiliki pengaruh terhadap keputusan hedging (Saragih \& Musdholifah, 2017). Hasil berbeda dengan Aristya \& E Hidajah (2020), bahwa growth opportunity tidak memiliki pengaruh terhadap keputusan hedging. Growth opportunity yang tinggi mengakibatkan kemungkinan perusahaan melakukan hedging tinggi karena perusahaan dalam mendanai pertumbuhannya akan lebih memilih melalui utang sehingga perusahaan melakukan hedging guna meminimalisir risiko fluktuasi nilai tukar yang timbul dari utang dalam bentuk valuta asing (Aslikan \& Rokhmi, 2015). Teori yang mendukung dalam hal ini adalah signaling theory. Growth opportunity yang dimiliki perusahaan tinggi maka perusahaan memiliki keputusan hedging tinggi (Astyrianti \& Sudiartha 2017).

H2: Growth opportunity berpengaruh terhadap keputusan hedging perusahaan sektor pertanian tahun 2013-2019.

Leverage digambarkan melalui seberapa banyak kegiatan operasional perusahaan yang dibiayai oleh utang. Leverage memiliki pengaruh terhadap keputusan hedging (Kurniawan \& Asandimitra, 2018). Namun Idawati \& Redawati (2019), leverage tidak memiliki pengaruh terhadap keputusan hedging. Leverage yang tinggi mengakibatkan kemungkinan perusahaan melakukan hedging tinggi karena perusahaan yang didanai utang tinggi akan menyebabkan terjadinya risiko gagal bayar sehingga perlu dilakukan hedging guna meminimalisir risiko terjadinya depresiasi nilai rupiah terhadap utang dalam bentuk valuta asing, sesuai dengan trade-off theory. Tingginya kemungkinan perusahaan memilih untuk melakukan hedging disebabkan oleh rasio leverage perusahaan tinggi (Guniarti, 2014).

H3: Leverage berpengaruh terhadap keputusan hedging perusahaan sektor pertanian tahun 20132019.

Rasio likuiditas dapat mengindikasi daya mampu perusahaan dalam melunasi utang lancarnya. Likuiditas memiliki pengaruh terhadap keputusan hedging (Astyrianti \& Sudiartha, 2017), berbeda dengan Prabawati \& Damayanti (2019), bahwa likuiditas tidak memiliki pengaruh terhadap keputusan 

2019

hedging. Likuiditas yang rendah mengakibatkan perusahaan memiliki kemungkinan melakukan hedging tinggi karena ketika tingkat likuiditas perusahaan rendah maka kewajiban lancarnya akan sulit dipenuhi dan jika kewajiban didenominasi valuta asing pada saat terjadi pelemahan mata uang maka akan memerburuk keadaan sehingga diperlukan hedging guna memanajemen risiko tersebut, hal ini didukung oleh pecking order theory. Perusahaan dengan likuiditas yang rendah dapat menyebabkan keputusan hedging yang dipilih perusahaan tinggi (Kussulistyanti \& Mahfudz 2016).

H4: Likuiditas berpengaruh terhadap keputusan hedging perusahaan sektor pertanian tahun 20132019.

Luasnya aktivitas bisnis yang dilakukan perusahaan digambarkan melalui tingginya tingkat profitabilitas perusahaan. Profitabilitas memiliki pengaruh terhadap keputusan hedging (Hadinata \& Hardianti, 2019) bertentangan dengan Aristya \& E Hidajah (2020), bahwa profitabilitas tidak memiliki pengaruh terhadap keputusan hedging. Profitabilitas yang tinggi mengakibatkan perusahaan memiliki kemungkinan melakukan hedging tinggi karena dengan profitabilitas tinggi mampu mendorong perusahaan memerluas usaha hingga internasional sehingga perlu dilakukan hedging untuk meminimalisir risiko fluktuasi kurs mata uang dari transaksi yang dilakukan, hal ini didukung oleh $d u$ pont theory. Profitabilitas perusahaan yang semakin tinggi mampu menjadikan keputusan hedging perusahaan juga semakin tinggi (Hadinata \& Hardianti 2019).

H5: Profitabilitas berpengaruh terhadap keputusan hedging perusahaan sektor pertanian tahun 20132019.

\section{METODE PENELITIAN}

Pendekatan secara kuantitatif dipilih dalam melakukan analisis terkait hubungan hedging sebagai variabel dependen terhadap varibel independen yakni ukuran perusahaan, likuiditas, profitabilitas, growth opportunity, dan leverage. Data yang digunakan adalah data sekunder dan diakses dari website idx.co.id. Jumlah populasi yang digunakan adalah 23 perusahaan sektor pertanian yang tercatat di Bursa Efek Indonesia tahun 2013-2019. Periode pengamatan ditentukan pada kurun waktu 7 tahun dimulai yaitu tahun 2013 hingga tahun 2019. Teknik pengambilan sampel dengan purposive sampling memiliki kriteria: (1) perusahaan mempunyai laporan keuangan tahunan yang sudah di audit selama periode penelitian,(2) perusahaan mempunyai eksposur valuta asing yang muncul karena tidak adanya aset dan kewajiban dalam valuta asing, penjualan ekspor, impor bahan baku atau memiliki anak perusahaan di luar negeri, dan (3) perusahaan mempunyai history closing price selama periode penelitian, sehingga diperoleh 11 sampel perusahaan. Analisis data menggunakan analisis regresi logistik dengan program SPSS. Tahapan yang dilalui yaitu uji keseluruhan model, uji kelayakan model regresi, dan uji parameter.

\section{HASIL DAN PEMBAHASAN}

Langkah awal yang dilakukan ialah penilaian overall fit model. H0 harus diterima supaya mendapatkan model yang fit. Nilai statistik -2LogL dengan hanya konstanta tanpa variabel sebesar 99,769 dan nilai statistik dengan konstanta dan variabel bebas ukuran perusahaan, likuiditas, profitabilitas, growth opportunity, dan leverage sebesar 86,439. -2LogL dengan konstanta dan variabel tidak signifikan pada alpha 5\% yang mengindikasi hipotesis nol diterima dan model fit dengan data. Cox and Sneel's $R$ Square merupakan bentuk dari ukuran $R$ Square yang ada pada multiple regression dalam regresi logistik (Ghozali, 2018:333).

Tabel 1, menggunakan model summary nilai Cox and Sneel's $R$ Square dan Negelkerke's $R$ Square yaitu 0,159 dan 0,219 menggambarkan bahwa keputusan hedging mampu dijelaskan dengan variabel independen sebesar sebesar 21,9\% dan 78,1\% dijelaskan dengan variabel lain diantaranya nilai perusahaan (Kurniawan \& Asandimitra, 2018), financial distress (Aditya \& Asandimitra, 2019), managerial ownership (Bodroastuti et al., 2019), solvabilitas (Aristya \& E Hidajah, 2020), dividend per share, cash flow volatility (Mahardini, Suprihatin, \& Nurzamzami, 2020). 
Tabel 1.

MODEL SUMMARY

\begin{tabular}{ccc}
\hline $\begin{array}{c}-2 \text { Log } \\
\text { likelihood }\end{array}$ & $\begin{array}{c}\text { Cox \& Snell } \boldsymbol{R} \\
\text { Square }\end{array}$ & $\begin{array}{c}\text { Nagelkerke } \\
\boldsymbol{R} \text { Square }\end{array}$ \\
\hline 86,439 & 0,159 & 0,219 \\
\hline Sumber $:$ Output SPSS $($ data diolah) &
\end{tabular}

Sumber : Output SPSS (data diolah)

Tabel 2.

HOSMER AND LEMESHOW TES

\begin{tabular}{ccc}
\hline Chi-square & df & Sig. \\
\hline 8,272 & 8 & 0,407 \\
\hline Sumber: Output SPSS (data diolah)
\end{tabular}

Tabel 2, dengan menguji kelayakan model regresi menggunakan Hosmer and Lemeshow Goodness of Fit Test menunjukkan nilai Hosmer and Lemeshow yaitu 8,272 dan siginifikan pada 0,407 hal ini menggambarkan bahwa model dapat diterima atau dapat dikatakan fit dan data observasi sesuai karena nilai signifikan yang lebih besar dari 0,05. Pada analisis regresi logistik yang memprediksi proyeksi perusahaan yang tidak melakukan hedging digambarkan pada angka 0 sebanyak 50 perusahaan sedangkan data yang ditunjukkan pada hasil observasi hanya 46, sehingga ketepatan klasifikasi sebesar 92\% (46/50). Proyeksi perusahaan yang memilih untuk melakukan hedging sebanyak 27 sedangkan data yang ditunjukkan pada hasil observasi hanya 17, sehingga ketepatan klasifikasi sebesar 37\% (17/27). Secara keseluruhan tingkat keakuratan klasifikasi pada model adalah $72,7 \%$.

Variabel independen yang diuji yaitu pengaruh ukuran perusahaan, likuiditas, profitabilitas, growth opportunity, dan leverage terhadap variabel dependen yaitu keputusan hedging perusahaan. Pengujian dilakukan menggunakan analisis regresi logistik dengan metode enter.

Tabel 3.

VARIABLE IN THE EQUATION

\begin{tabular}{lcc}
\hline & B & Sig. \\
\hline Ukuran_Perusahaan & 0,024 & 0,683 \\
Growth_Opportunity & 0,246 & 0,136 \\
Leverage & 4.191 & 0,059 \\
Likuiditas & $-0,208$ & 0,421 \\
Profitabilitas & 19,532 & 0,016 \\
Constant & $-3,877$ & 0,069 \\
\hline
\end{tabular}

Sumber : Output SPSS (data diolah)

Tabel 3, pada variable in the equation terdapat satu variabel yang memiliki p-value di bawah 0,05 yaitu Profitabilitas. Hal ini berarti bahwa variabel independen yang signifikan terhadap profitabilitas, sehingga diketahui log of odds keputusan hedging perusahaan dipengaruhi oleh profitabilitas secara positif. Setiap unit peningkatan profitabilitas akan menjadikan log of odds keputusan hedging perusahaan naik dengan angka sebesar 19,532.

\section{Pengaruh Ukuran Perusahaan terhadap Keputusan Hedging Perusahaan.}

Variabel ukuran perusahaan yang dihitung menggunakan logaritma natural dari total aset tidak memiliki pengaruh terhadap keputusan hedging perusahaan karena ukuran perusahaan yang besar mampu menggambarkan kemampuan perusahaan memenuhi kewajibannya sehingga perusahaan tidak perlu melakukan hedging maka hal ini tidak mendukung teori portofolio. Menurut Aditya \& Asandimitra (2019), Nur et al. (2020), dan Wahyudi et al.(2019), ukuran perusahaan tidak 
memengaruhi perusahaan dalam memilih keputusan hedging. Hal ini didukung dengan ukuran perusahaan PT Jaya Agra Wattie Tbk. yaitu 28,75 dengan total aset senilai Rp2.659.037.365.483 di tahun 2013. Ukuran PT Jaya Agra Wattie Tbk. yang besar tersebut memerlihatkan adanya aktivitas perusahaan yang luas. PT Jaya Agra Wattie Tbk. terlibat dalam berbagai perdagangan internasional. Aktivitas tersebut menjadikan adanya transaksi dalam valuta asing, namun hal ini tidak membuat PT Jaya Agra Wattie Tbk. untuk melakukan hedging setiap tahunnya. Hasil ini memberikan implikasi bahwa besarnya ukuran perusahaan mengindikasi luasnya aktivitas usaha perusahaan. Adanya aktivitas usaha internasional menjadikan perusahaan mengalami eksposur fluktuasi valuta asing. Total aset perusahaan yang besar mampu menggambarkan perusahaan yang memiliki tingkat kesiapan dalam memenuhi kewajiban perusahaan, sehingga masalah keuangan perusahaan dapat teratasi (Wahyudi et al.2019). Dengan demikian ukuran perusahaan tidak perlu menjadi indikator dari pengambilan keputusan hedging.

\section{Pengaruh Growth Opportunity terhadap Keputusan Hedging Perusahaan.}

Variabel growth opportunity yang dihitung dengan membagi MVE dengan BVE tidak memengaruhi perusahaan dalam mengambil keputusan hedging, karena perusahaan dapat menggunakan laba ditahan untuk memenuhi pendanaan peluang pertumbuhannya sehingga perusahaan tidak perlu melakukan hedging. Hasil ini tidak mendukung signaling theory. Menurut Bodroastuti et al. (2019), Aristya \& E Hidajah (2020), dan Wahyudi et al., (2019), bahwa growth opportunity tidak memengaruhi perusahaan dalam melakukan keputusan hedging. Hal ini dibuktikan pada perusahaan PT BISI International Tbk dengan nilai growth opportunity tinggi di atas rata-rata $(-0,1240)$ yaitu 2,77 dan menetapkan keputusan tidak hedging memiliki utang sebesar Rp352.652.000.000 dan laba ditahan Rp1.598.657.000.000 pada tahun 2016. Hal ini menandakan bahwa utang perusahaan lebih kecil dibandingkan laba ditahan perusahaan, yang berarti PT BISI International Tbk lebih memilih laba ditahan untuk mendanai peluang pertumbuhannya. Hasil ini memberikan implikasi bahwa dalam memilih keputusan hedging perusahaan tidak perlu meninjau besarnya growth opportunity perusahaan karena growth opportunity perusahaan tidak memengaruhi keputusan hedging yang diambil (Aristya \& E Hidajah 2020). Dengan hal ini maka laba ditahan perusahaan dapat digunakan sebagai antisipasi risiko dari growth opportunity guna terpenuhinya kebutuhan dana perusahaan.

\section{Pengaruh Leverage terhadap Keputusan Hedging Perusahaan.}

Variabel leverage yang memiliki proksi DAR menunjukkan bahwa leverage tidak memengaruhi perusahaan dalam mengambil keputusan hedging karena untuk mendapatkan laba yang maksimal perusahaan dapat memerhatikan beban bunga yang ada, beban bunga yang meningkat beriringan dengan pendapatan yang juga meningkat sehingga perusahaan tidak perlu melakukan hedging maka hasil ini tidak mendukung trade-off theory. Menurut Aditya \& Asandimitra (2019), Bodroastuti et al., (2019), Idawati \& Redawati (2019) dan Wahyudi et al., (2019) yang menjelaskan bahwa leverage tidak memengaruhi perusahaan dalam memilih keputusan hedging. Hal ini didukung dengan data bahwa PT Provident Agro Tbk. yang memiliki keputusan tidak hedging meskipun mengalami fluktuasi rasio leverage dari tahun 2013 hingga 2019. Hasil ini memberikan implikasi bahwa perusahaan tidak perlu memerhatikan tingkat leverage pada saat akan mengambil keputusan hedging karena ketika laba yang maksimal menjadi tujuan dari penggunaan leverage maka tingkat beban bunga perusahaan dapat menjadi antisipasi risiko yang dapat diambil (Idawati \& Redawati 2019).

\section{Pengaruh Likuiditas terhadap Keputusan Hedging Perusahaan.}

Variabel likuiditas yang memiliki proksi current ratio menunjukkan bahwa likuiditas tidak memengaruhi perusahaan dalam mengambil keputusan hedging karena apabila perusahaan memiliki utang dalam bentuk valuta asing ketika memiliki proporsi utang tinggi akan memperbesar risiko yang ada. Hasil ini tidak mendukung pecking order theory. Menurut Bodroastuti et al., (2019), Aslikan \& Rokhmi (2015), Prabawati \& Damayanti (2019), dan Nur et al., (2020) yang menjelaskan bahwa likuiditas tidak memengaruhi perusahaan dalam memilih keputusan hedging. Hasil ini menunjukkan likuiditas PT Eagle High Plantations Tbk. yang rendah di bawah rata-rata (1,5152) menjadikan perusahaan memutuskan untuk tidak hedging. Tingkat likuiditas PT Eagle High Plantations Tbk. pada tahun 2017 sebesar 0,5. Tingkat likuiditas tersebut menunjukkan bahwa setiap 1 utang lancar perusahaan dijamin oleh 0,5 aset lancarnya. Hal ini menunjukkan perusahaan tidak mempunyai 
kemampuan besar dalam memenuhi utang lancarnya. Selain itu, jumlah aset lancar yang kecil tersebut tidak dapat digunakan sebagai dana cadangan perusahaan ketika utang yang didenominasi valuta asing menjadi lebih besar pada saat terjadi depresiasi nilai tukar. Hasil ini memberikan implikasi bahwa dalam mengambil keputusan hedging perusahaan tidak perlu melihat likuiditas perusahaan sebagai indikatornya. Tingkat likuiditas perusahaan yang rendah maka mengindikasi tingginya risiko perusahaan mengalami gagal bayar karena utang yang berbentuk valuta asing akan menjadikan risiko tersebut semakin besar sehingga perusahaan tidak disarankan melakukan keputusan hedging jika proporsi utang tinggi (Prabawati \& Damayanti 2019).

\section{Pengaruh Profitabilitas terhadap Keputusan Hedging Perusahaan.}

Variabel profitabilitas yang diproksikan dengan return on assets memperlihatkan bahwa profitabilitas dapat memengaruhi perusahaan dalam memilih keputusan hedging karena perluasan usaha hingga internasional yang diakibatkan oleh tingginya profitabilitas menyebabkan diperlukan hedging untuk antisipasi risiko fluktuasi kurs mata uang, sehingga hasil ini mendukung du pont theory. Menurut Ariani \& Sudiartha (2017), Kurniawan \& Asandimitra (2018), Saraswati \& Suryantini (2019), Limbong \& Hutabarat (2020), dan Hadinata \& Hardianti (2019) profitabilitas memengaruhi perusahaan dalam memilih keputusan hedging. Hal ini dibuktikan dengan tingkat profitabilitas PT Jaya Agra Wattie Tbk. yang rendah yaitu -0,06. Hal ini kemudian membuat PT Jaya Agra Wattie Tbk. memiliki keputusan tidak hedging. Sedangkan PT Astra Agro Lestari Tbk. memiliki profitabilitas yang tinggi yaitu 0,09. Hal ini kemudian membuat PT Astra Agro Lestari Tbk. memutuskan untuk melaksanakan hedging. Hasil ini memberikan implikasi bahwa tingkat profitabilitas perusahaan yang tinggi akan mengakibatkan perusahaan memperluas aktivitas usaha hingga ke berbagai negara, perusahaan yang melakukan transaksi dengan berbagai negara akan memperoleh pendapatan dalam mata uang yang berbeda (Hadinata \& Hardianti 2019). Adanya pendapatan dalam valuta asing membuat perusahaan memiliki risiko perbedaan kurs mata uang sehingga mengakibatkan perusahaan yang memiliki tingkat profitabiltas tinggi memilih keputusan hedging sebagai upaya manajemen risiko dari perbedaan nilai tukar mata uang (Kurniawan \& Asandimitra 2018).

\section{KESIMPULAN}

Ukuran perusahaan tidak memiliki pengaruh dalam mengambil keputusan hedging perusahaan karena perusahaan dengan total aset yang tinggi dapat menggambarkan kesiapannya dalam memenuhi kewajiban perusahaan, sehingga tidak diperlukan untuk melakukan hedging. Growth Opportunity tidak berpengaruh terhadap keputusan hedging karena growth opportunity yang dimiliki perusahaan membuat perusahaan dalam memenuhi kebutuhannya memilih menggunakan laba ditahan. Laba ditahan digunakan oleh perusahaan sebagai upaya dalam mencegah terjadinya kebangkrutan dimasa mendatang. Leverage tidak memiliki pengaruh dalam mengambil keputusan hedging perusahaan karena leverage tidak akan menimbulkan risiko yang besar selama pendapatan perusahaan yang berasal dari pendanaan eksternal tidak lebih kecil dari beban bunga perusahaan. Likuiditas tidak memiliki pengaruh dalam mengambil keputusan hedging perusahaan karena apabila perusahaan memiliki utang dalam bentuk valuta asing ketika memiliki proporsi utang tinggi akan memperbesar risiko yang ada. Profitabilitas berpengaruh terhadap keputusan hedging karena profitabilitas perusahaan yang tinggi mengindikasi luasnya aktivitas operasional perusahaan dan memperoleh pendapatan mata uang asing sehingga perusahaan perlu melalukan hedging untuk meminimalisir risiko fluktuasi kurs mata uang.

Perusahaan diharapkan lebih memerhatikan profitabilitas yang dimiliki supaya dapat mengambil keputusan yang tepat terkait keputusan hedging dalam upaya meminimalisir berbagai risiko yang dihadapi dan bagi investor diharapkan untuk memerhatikan manajemen risiko pada perusahaan seperti hedging guna meminimalisir kerugian yang mungkin terjadi. Hasil ini memiliki keterbatasan yang dihasilkan yaitu nilai Negelkerke's $R$ Square hanya sebesar 21,9\% hal ini menunjukkan bahwa masih ada $78,1 \%$ variabel lain yang dapat menerangkan pengaruh dalam mengambil keputusan hedging perusahaan. Untuk selanjutnya variabel profitabilitas dapat menjadi pertimbangan dalam pengujian. 
Irfani Azzah Nabiilah. Determinasi Keputusan Hedging Perusahaan Publik Sektor Pertanian 20132019

Profitabilitas dengan proksi return on assets dapat mengindikasi tingkat efektif dan efisien perusahaan dalam menggunakan aset untuk menghasilkan laba perusahaan.

\section{DAFTAR PUSTAKA}

Aditya, A. T., \& Asandimitra, N. (2019). Pengaruh Leverage, Likuiditas, Market To Book Value, Financial Distress, dan Firm Size Terhadap Keputusan Hedging (Studi Perusahaan Sektor Consumer Goods Industri Periode 2011-2016). Jurnal Ilmu Manajemen (JIM) (Vol. 7, pp. 334343).

Ambarwati, S. D. A. (2010). Manajemen Keuangan Lanjut. Yogyakarta: Graha Ilmu.

Ariani, N., \& Sudiartha, G. (2017). Pengaruh Leverage, Profitabilitas, dan Likuiditas terhadap Keputusan Hedging Perusahaan Sektor Pertambangan di Bursa Efek Indonesia. E-Jurnal Manajemen, 6(1), 347-374.

Aristya, M., \& E Hidajah, W. (2020). Faktor-Faktor yang Memengaruhi Keputusan Hedging dengan Instrumen Derivatif (Studi pada Perusahaan yang Terdaftar di BEI Tahun 2016-2018). Jurnal Ilmiah Mahasiswa FEB, 8(2), 1-18.

Aslikan, I., \& Rokhmi, S. (2015). Faktor-Faktor yang Mempengaruhi Keputusan Hedging pada Perusahaan Manufaktur. Jurnal Ilmu Dan Riset Manajemen, 6(5), 1-21.

Astyrianti, N., \& Sudiartha, G. (2017). Pengaruh Leverage, Kesempatan Tumbuh, Kebijakan Dividen dan Likuiditas terhadap Keputusan Hedging PT. Unilever Tbk. E-Jurnal Manajemen Universitas Udayana, 6(3), 1312-1339.

Bodroastuti, T., Paranita, E. S., \& Ratnasari, L. (2019). Faktor-Faktor yang Berpengaruh terhadap Kebijakan Hedging Perusahaan di Indonesia. Valid Jurnal Ilmiah, 16(1), 71-84.

Brigham, E. F., \& Houston, J. F. (2014). Dasar Dasar Manajemen Keuangan. Jakarta: Salemba Empat.

Diah Windari, I. G. M., \& Purnawati, N. K. (2019). Pengaruh Leverage, Ukuran Perusahaan, dan Likuiditas terhadap Keputusan Hedging pada Perusahaan Manufaktur Terdaftar di BEI. EJurnal Manajemen Universitas Udayana, 8(8), 4815-4840. https://doi.org/10.24843/ejmunud.2019.v08.i08.p04

Fahmi, I. (2012). Analisis Kinerja Keuangan. Bandung: Alfabeta.

Ghozali, I. (2018). Aplikasi Analisis Multivariate dengan Program SPSS 25. Semarang: Badan Penerbit Universitas Diponegoro.

Guniarti, F. (2014). Faktor-Faktor yang Mempengaruhi Aktivitas Hedging dengan Instrumen Derivatif Valuta Asing. Jurnal Dinamikan Manajemen, 5(1), 64-79.

Hadinata, S., \& Hardianti, D. A. (2019). Variabel Fundamental Perusahaan dalam Memprediksi Keputusan Hedging. Akuntabilitas, 12(2), 179-190. https://doi.org/10.15408/akt.v12i2.11823

Horne, J. C., Van, \& Wachowicz Jr, J. M. (2013). Prinsip-Prinsip Manajemen Keuangan. Jakarta: Salemba Empat.

Idawati, I., \& Redawati. (2019). Pengaruh Market To Book Value, Likuiditas dan Leverage terhadap Keputusan Hedging pada Perusahaan Sektor Keuangan yang Terdaftar di BEI. Sains Manajemen Dan Kewirausahaan, 3(1), 1-7. 
Indawan, F., Fitriani, S., Karlina, I., \& Grace, M. V. (2015). The Role of Currency Hedging on Firm Performance: a Panel Data Evidence in Indonesia. Buletin Ekonomi Moneter Dan Perbankan, 17(3), 279-298. https://doi.org/10.21098/bemp.v17i3.39

Indonesia, B., \& Republik Indonesia, K. K. (2020). Statistik Utang Luar Negeri Indonesia Vol: X Oktober 2020.

Kasmir. (2016). Analisis Laporan Keuangan. Jakarta: Rajawali Pers.

Keown, A. J., Martin, J. D., Petty, J. W., \& Junior, D. F. S. (2010). Manajemen Keuangan: Prinsip dan Penerapan. Jakarta: PT. Indeks.

Kodrat, D. S., \& Herdinata, C. (2009). Manajemen Keuangan based on Emprical Research. Yogyakarta: Graha Ilmu.

Kurniawan, D. P., \& Asandimitra, N. (2018). Analisis Faktor yang Mempengaruhi Penggunaan Instrumen Derivatif sebagai Pengambilan Keputusan Hedging pada Perusahaan Sektor Keuangan yang Terdaftar di BEI Periode 2011-2015. Jurnal Ilmu Manajemen (JIM), 6(1), 111.

Kussulistyanti, M. J. W. A., \& Mahfudz. (2016). Analisis Faktor-Faktor yang Mempengaruhi Keputusan Hedging dengan Derivatif Valuta Asing (Studi pada Perusahaan Non- Finansial yang Terdaftar di Bursa Efek Indonesia Periode Tahun 2011-2014). Diponegoro Journal of Management, 5(3), 1-14.

Limbong, G. H. L., \& Hutabarat, F. M. (2020). Effect of Liquidity , Leverage , and Profitability on Consumption Company Hedging on Companies Listed the Indonesia Stock Exchange from 2012-2018. International Conference on Strategic Mental Revolution (ICoSMR), 37-49.

Madura, J. (2012). International Financial Management (11th ed.). South-Western: Cengage Learning.

Mahardini, N. Y., Suprihatin, N. S., \& Nurzamzami, F. (2020). Does Leverage, Dividend Per Share, and Cash Flow Volatility Affect Hedging Decisions?: An Empirical Study on Listed Manufacturing Companies. Journal of Accounting Auditing and Business, 3(2), 104-111.

Nur, H. V. A., Djaelani, A. K., \& Priyono, A. A. (2020). Pengaruh Firm Size, Growth Opportunity dan Likuiditas terhadap Pengambilan Keputusan Hedging (Studi pada Perusahaan Manufaktur yang Terdaftar di Bursa Efek Indonesia Tahun 2016-2018). E- Jurnal Riset Manajemen, 145160.

Prabawati, N. P. H., \& Damayanti, C. R. (2019). Pengaruh Faktor Debt to Equity Ratio , Market to Book Value, dan Liquidity terhadap Keputusan Hedging dengan Menggunakan Instrumen Derivatif ( Studi pada Perusahaan Manufaktur yang Terdaftar di Bursa Efek Indonesia Periode 2014 - 2017 ). Jurnal Administrasi Bisnis (JAB), 69(1), 40-49.

Rahardjo, B. (2007). Keuangan dan Akuntansi untuk Manajer Non Keuangan. Yogyakarta: Graha Ilmu.

Saragih, F., \& Musdholifah. (2017). Pengaruh Growth Opportunity, Firm Size, dan Liquidity terhadap Keputusan Hedging pada Perusahaan Perbankan Indonesia. Jurnal Ilmu Manajemen (JIM), $5(2), 1-10$.

Saraswati, A. P. S., \& Suryantini, N. P. S. (2019). Pengaruh Leverage, Firm Size, Profitabilitas terhadap Keputusan Hedging pada Perusahaan Manufaktur di Bursa Efek Indonesia. E-Jurnal 
Irfani Azzah Nabiilah. Determinasi Keputusan Hedging Perusahaan Publik Sektor Pertanian 20132019

Manajemen Universitas Udayana, 8(5), 2999-3027. https://doi.org/10.24843/ejmunud.2019.v08.i05.p15

Sasmita, I. E., \& Hartono, U. (2019). Karakteristik Perusahaan, Financial Distress, dan Keputusan Hedging: Studi pada Perusahaan Manufaktur di Indonesia. Jurnal Ilmu Manajemen, 7(1), 655667.

Sudana, I. M. (2015). Manajemen Keuangan Perusahaan Teori dan Praktik. Jakarta: Erlangga.

Tandelilin, E. (2010). Portofolio dan Investasi. Yogyakarta: Kansius.

Wahyudi, S., Goklas, F., Rita, M. R., Hersugondo, H., \& Laksana, R. D. (2019). The determinants of Corporate Hedging Policy: A Case Study from Indonesia. International Journal of Economics and Business Administration, 7(1), 113-129. https://doi.org/10.35808/ijeba/199

Wayan, N., Mitariani, E., Sedana, I. B. P., \& Badjra, I. B. (2013). Analisis Perbandingan Penggunaan Hedgingantara Forward Contract dengan Currency Swap untuk Meminimasi Risiko Foreign Exchange. Jurnal Manajemen, Strategi Bisnis Dan Kewirausahaan, 7(1), 1-8. 